For Strasbourg 
This page intentionally left blank 


\title{
For Strasbourg
}

\section{Conversations of Friendship and Philosophy}

\author{
JACQUES DERRIDA
}

Edited and Translated by Pascale-Anne Brault and Michael Naas 


\section{Copyright (C) 20I4 Fordham University Press}

All rights reserved. No part of this publication may be reproduced, stored in a retrieval system, or transmitted in any form or by any means-electronic, mechanical, photocopy, recording, or any other-except for brief quotations in printed reviews, without the prior permission of the publisher.

This book brings together four texts that were originally published in French under the following titles: "Le lieu dit: Strasbourg," by Jacques Derrida, in Penser à Strasbourg (C) Éditions Galilée, 2004; "Dialogue entre Jacques Derrida, Philippe Lacoue-Labarthe, and Jean-Luc Nancy," in Rue Descartes, no. 52 (2006): 86-99, (C) Succession Derrida/Succession Lacoue-Labarthe/Jean-Luc Nancy; "Ouverture," discussion avec Jean-Luc Nancy, Rue Descartes 45 (2004): 26-55, (C) Succession Derrida/Jean-Luc Nancy; "Résponsabilité du sens a venir," conversation avec Jean-Luc Nancy, in Sens en tous sens: Autour des travaux de JeanLuc Nancy, (C) Éditions Galilée, 2004.

Fordham University Press also publishes its books in a variety of electronic formats. Some content that appears in print may not be available in electronic books.

\section{Library of Congress Cataloging-in-Publication Data}

Derrida, Jacques.

[Essays. Selections. English]

For Strasbourg : conversations of friendship and philosophy / Jacques Derrida ; edited and translated by Pascale-Anne Brault and Michael Naas.

pages $\mathrm{cm}$

Includes bibliographical references.

Summary: "For Strasbourg consists of a series of essays and interviews by French philosopher and literary theorist Jacques Derrida (1930-2004) about the city of Strasbourg and the philosophical friendships he developed there over a forty year period. It is a profound interrogation of the relationship between philosophy and place, philosophy and language, and philosophy and friendship"-Provided by publisher.

ISBN 978-0-8232-5648-8 (hardback)—ISBN 978-0-8232-5649-5 (paper)

I. Derrida, Jacques-Friends and associates. 2. Philosophy-France.

3. Philosophers-France-Interviews. 4. Nancy, Jean-Luc-Interviews.

5. Lacoue-Labarthe, Philippe-Interviews. 6. Strasbourg (France)—Intellectual life.

I. Title.

B2430.D482E5 2014

194-dc23

Published in the United States of America

I6 I5 I4 $54 \begin{array}{llll}4 & 3 & 2 & \text { I }\end{array}$

First edition 